\title{
Repair of an extensive iatrogenic tracheal rupture with a pleural patch and a vascular graft
}

\author{
Geniş iyatrojenik trakea rüptürünün vasküler ve \\ plevral yama ile onarımı
}

\author{
Erdal Birol BOSTANCI, ${ }^{1}$ İler ÖZER, ${ }^{1}$ Feza EKIZ, ${ }^{1}$ Ali Emre ATICI, ${ }^{1}$ Enver REYHAN, ${ }^{1}$ \\ Musa AKOĞLU, ${ }^{1}$ Atakan ERKILINÇ, ${ }^{2}$ Cevat YAKUT $^{3}$
}

\begin{abstract}
Here we describe a 48-year-old woman who suffered a $7-\mathrm{cm}$ rupture in the lower trachea after intubation with a double-lumen tube. We repaired the rupture with a new technique using a pleural patch reinforced by a ringed vascular graft. This technique appears to be appropriate for use in patients who have large tracheal ruptures to avoid tracheal stenosis.
\end{abstract}

Key Words: Double-lumen endotracheal tube; pleural patch; tracheal rupture.
Biz burada çift lümenli endotrakeal tüp ile entübasyon sonrasında $7 \mathrm{~cm}$ 'lik trakeal rüptür oluşan 48 yaşındaki hastayı sunmak istiyoruz. Ringli vasküler greft ile desteklenmiş plevral yama kullanılarak yeni bir teknik ile trakea yaralanması onarıldı. Bu tekniğin büyük trakea yaralanması olan hastalarda kullanımı trakea stenozunu önleme açısından uygun olabilir.

Anahtar Sözcükler: Çift lümenli endotrakeal tüp; plevral yama; trakea rüptürü.
Tracheobronchial rupture occurs rarely after single- or double-lumen endobronchial intubation, but is a life-threatening injury because it can lead to respiratory failure. The diagnosis is not difficult if the injury obviously impairs the respiratory parameters and the physician is aware of the possibility that a tracheobronchial rupture has occurred.

We describe herein a 48-year-old woman who experienced a rupture in the lower trachea after intubation with a double-lumen tube. We repaired the rupture with a new technique using a pleural patch reinforced by a ringed vascular graft.

\section{CASE REPORT}

A 48-year-old woman (weight $64 \mathrm{~kg}$, height 1.61 m) was admitted to our hospital with a diagnosis of adenocarcinoma in the middle part of the intrathoracic esophagus. No distant metastases were found during the preoperative evaluation, and the patient underwent a three-stage esophagectomy.

A left-sided double-lumen endobronchial tube (37 French) was placed with some difficulty with the use of a stylet. Dissection of the esophagus was performed without difficulty and the adjacent organs were not found to be invaded. The tumor was located in the

\footnotetext{
Presented at the 18th World Congress of the International Association of Surgeons, Gastroenterologists and Oncologists (October 8-11, 2008, Istanbul, Turkey).

Departments of ${ }^{1}$ Gastrointestinal Surgery, ${ }^{2}$ Anesthesiology and Reanimation, ${ }^{3}$ Cardiovascular Surgery, Kartal Kosuyolu Yuksek Ihtisas Training and Research Hospital, Istanbul, Turkey.
} 
middle third of the esophagus, inferior to the carina. The abdominal, thoracic and cervical steps of the operation were uneventful. A chest tube was inserted in the right hemithorax. The patient's physiologic parameters were normal throughout the operation.

Just after the operation, while the patient was still on the operating table, the double-lumen tube was replaced by a standard single-lumen endotracheal tube, and subcutaneous emphysema occurred in the upper region of the right hemithorax.

While the patient was being transported to the intensive care unit, the chest tube was clamped, and therefore air leakage from the tube was not apparent. However, by the time the patient arrived in the unit, her subcutaneous emphysema had increased obviously. She had severe cyanosis and her ventilatory parameters were deteriorating. Blood gas evaluation revealed an increased $\mathrm{PCO}_{2}(76 \mathrm{mmHg})$, a decreased $\mathrm{PO}_{2}(53 \mathrm{mmHg})$, and severe acidosis ( $\left.\mathrm{pH} 7.12\right)$. When the chest tube clamp was removed, a large amount of gas leakage was noted. The patient's hemodynamic status deteriorated due to hypoventilation and the resulting hypoxia.

A chest X-ray showed severe right-sided pneumothorax despite the presence of the chest tube in the right hemithorax. Because the patient's condition had markedly worsened after placement of the singlelumen endotracheal tube, this was replaced with a left-sided double lumen tube, as had been used previously. As soon as the left lumen balloon was inflated, the leakage of air from the chest tube ceased. When the balloon was deflated, the leakage was observed again, and upon reinflation the leakage stopped. After placement of the double-lumen tube, the patient's physiologic parameters improved; $\mathrm{PCO}_{2}$ decreased to $46 \mathrm{mmHg}, \mathrm{PO}_{2}$ increased to $93 \mathrm{mmHg}$, and $\mathrm{pH}$ increased from 7.12 to 7.3. Her blood pressure returned to normal. Bronchoscopy, which could have been used to confirm the rupture, was unfortunately not available at the time.

Collectively, the patient's findings indicated a tracheal and/or bronchial rupture on the right side. The patient was evaluated by cardiothoracic surgeons, and as her general condition and hemodynamic status were stable after the insertion of the double-lumen tube, reoperation to repair the rupture was performed the following morning to provide better conditions. The patient's general condition and hemodynamic parameters remained stable until the reoperation. For this second operation, the right thoracotomy incision was reopened. A 7-cm long rupture in the posterior (membranous) aspect of the trachea was found just above the carina. To repair the tracheal injury, an $8 \mathrm{~cm} \times 2 \mathrm{~cm}$ patch was harvested from the pleura. This was hard- ened by exposure to glutaraldehyde as follows. The patch was spread flat; $1 \mathrm{ml}$ of a $25 \%$ solution of glutaraldehyde was mixed with $1 \mathrm{ml}$ of physiologic saline, and this mixture was squirted onto the patch with a syringe. After a few seconds, the patch was washed 3 times with physiologic saline.

Around the tracheal rupture site, interrupted 3-0 polypropylene sutures (Prolene ${ }^{\circledR}$, Ethicon, Inc., Somerville, NJ, USA) were placed at a distance of 5 $\mathrm{mm}$ from the edge of the wound, and separated from each other by intervals of $1 \mathrm{~cm}$. These sutures were left untied. The pleural patch was then trimmed to a spindle shape so as to cover the tracheal rupture site and was attached to the edges of the wound with continuous 5-0 polypropylene sutures. A ringed vascular graft made of polytetrafluoroethylene (Gore-Tex ${ }^{\circledR}, \mathrm{W}$. L. Gore \& Associates, Inc., Flagstaff, AZ, USA) was then bisected along the long axis, with one half being further cut into shape so as to provide a slightly arched structure over the pleural patch for reinforcement. The shaped vascular graft was then placed over the pleural patch, and the two ends of each previously placed, as yet untied suture were then passed through the nearest part of the vascular graft, with one of the ends being on either side of a ring in the graft (Fig. 1). Thus, when the ends were tied, the knot was located on the ring in the graft. This was repeated for the other remaining sutures around the perimeter of the graft.

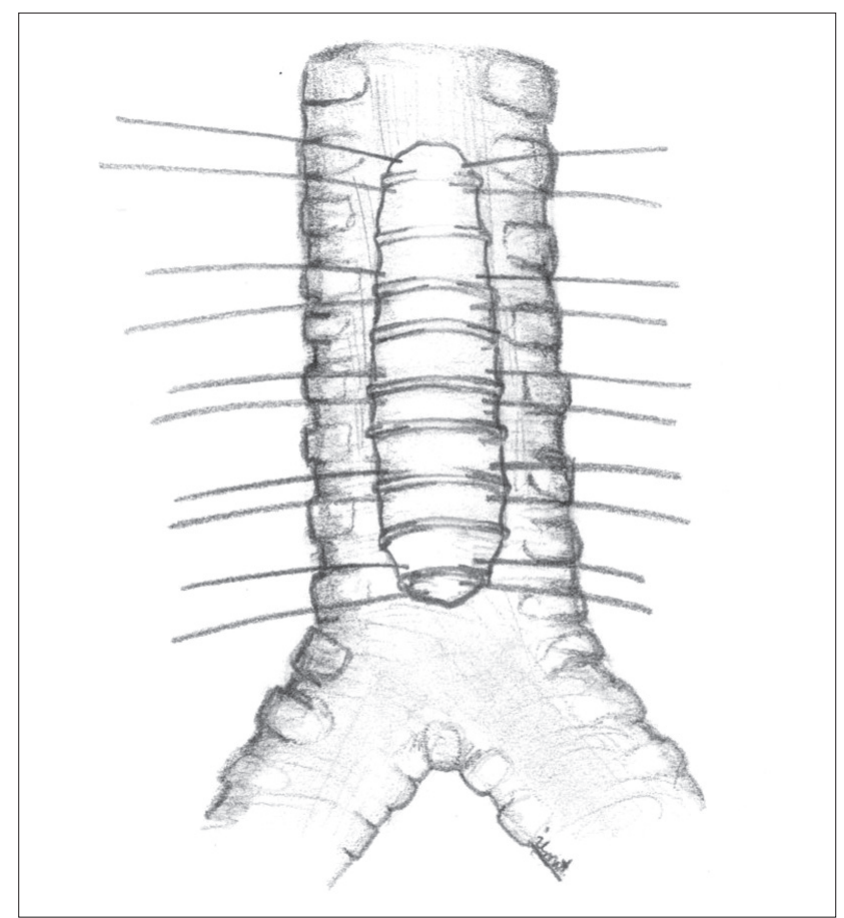

Fig. 1. After being trimmed into shape, the ringed vascular graft was positioned over the pleural patch and was sutured with the previously placed, as yet untied polypropylene sutures, with the two ends of each suture passing on opposite sides of a ring in the graft. 
Two chest tubes were placed in the right hemithorax and the incision was closed. The patient's postoperative course was uneventful and she was extubated the following day. The patient began oral feeding on postoperative day 10, and the chest tubes were removed on postoperative day 14. She experienced pneumonia, which was treated with systemic antibiotics, and she was discharged on postoperative day 21 with no respiratory or swallowing problems.

At a follow-up visit two months after the patient was discharged from the hospital, computed tomography and bronchoscopy showed no tracheal stenosis, and granulation tissue was observed on bronchoscopy (Fig. 2). The patient is now in the 9th month of followup and has had no further complaints.

\section{DISCUSSION}

Tracheobronchial rupture is a rare complication of procedures that involve the placement of instruments in the trachea or bronchi, such as bronchoscopy or intubation, especially intubation with double-lumen tubes. ${ }^{[1]}$ Risk factors include emergency intubation, multiple and vigorous attempts at intubation, inexperience in intubation, overinflation of the tube cuff, malposition of the tube, improper tube size, inappropriate use of stylets, abrupt movement by the patient, excessive coughing, female gender, and short stature. ${ }^{[1,2]}$ Our patient was female and of short stature, a stylet was used during her initial intubation, and the intubation was difficult.

The main clinical manifestations of tracheobronchial rupture are subcutaneous emphysema, hemoptysis and dyspnea. However, the diagnosis can be delayed because of varying intervals between occurrence of the rupture and onset of clinical symptoms. ${ }^{[3]}$ Intervals of up to 126 hours between injury and diagnosis have been reported. ${ }^{[4]}$ In our patient, tracheal rupture was diagnosed immediately because of the acute onset of severe symptoms and deterioration of respiratory parameters. As soon as a tracheal injury was suspected, the patient was reintubated with a left-sided double-lumen tube, the cuff was inflated, and the patient's general condition, blood gas values and hemodynamic parameters improved immediately.

While the patient was being transported to the intensive care unit, the chest tube was clamped, thus no air leak was seen. A clamped chest tube is dangerous in mechanically ventilated patients who undergo pulmonary surgery. In this patient, esophageal resection was performed. The right lung was inflated before the thoracotomy was closed, and no air leak was observed. We perform 20-25 esophagectomies per year and have not experienced any problem due to clamping. However, after this unexpected experience, we do not clamp the chest tubes, although we can transfer
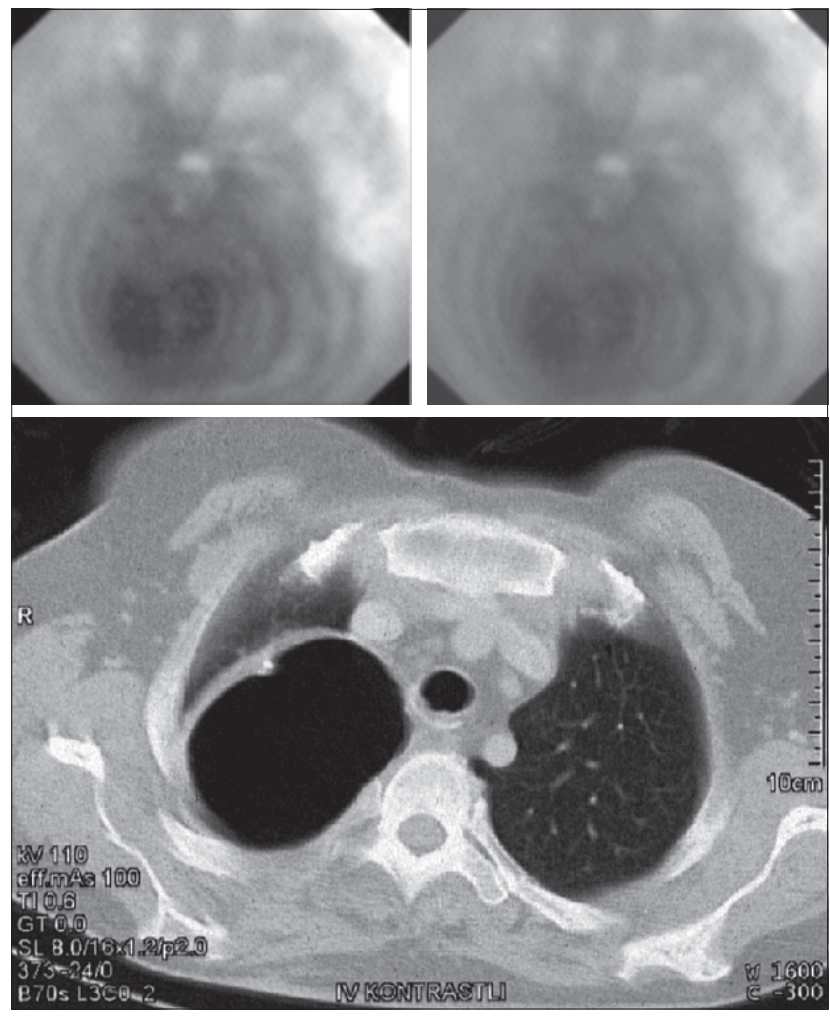

Fig. 2. Bronchoscopy image obtained two months after discharge from the hospital.

our patients to the intensive care unit in only a few minutes. Chest tubes should be left open against potential tracheobronchial or pulmonary injuries. This case emphasizes the importance of patient transfer after esophageal surgery.

Treatment for tracheobronchial rupture depends on the size and location of the injury and the patient's clinical presentation and general condition. ${ }^{[5]}$ Surgery is the main choice of treatment for the majority of patients. The outcome of treatment depends on the rapidity of diagnosis, because early treatment helps to minimize mediastinitis. Ruptures larger than $2 \mathrm{~cm}$, injuries involving the paracarinal region, presence of respiratory distress, rapidly increasing subcutaneous and mediastinal emphysema, and pneumothorax showing continuous air leak are indications for surgery. ${ }^{[1,5]}$

For the surgical repair of tracheal ruptures, various methods have been described, involving direct suturing of the trachea, ${ }^{[6]}$ which may be reinforced by flaps from nearby tissues such as the pectoralis muscle. ${ }^{[7]} \mathrm{A}$ method using a pericardial flap reinforced by a GoreTex $^{\circledR}$ soft tissue patch has been described, ${ }^{\left[{ }^{[8]}\right.}$ and free pericardial patch repair has also been used, with reinforcement provided by a pedicled muscle flap. ${ }^{[9]}$

A potential consequence of tracheal rupture and repair is tracheal stenosis, particularly in patients with small-caliber tracheas. In the repair of large tracheal 
ruptures, direct suturing of the torn edges of the rupture might therefore be less appropriate than the use of methods that do not involve direct apposition of the edges. For our patient, who had a small-caliber trachea and a large rupture, we preferred to use a pleural patch reinforced with a ringed polytetrafluoroethylene vascular graft to help avoid later tracheal stenosis. We considered a pleural patch to be more appropriate than one taken from the pericardium, because the presence of the right thoracotomy provided ready access to the pleura, whereas harvesting a pericardial graft would have required an additional procedure, possibly leading to further complications. The reason for using the pleura at all was to reduce the possibility of air leak, which would likely occur if the vascular graft was used alone. With this in mind, the pleural patch was attached to the torn tracheal edges with continuous sutures. The use of glutaraldehyde to harden the pleura made suturing easier. The rationale for using a ringed vascular graft was that it provides a slightly arched, reinforced structure to help prevent collapse of the pleural patch into the trachea. The rings also help prevent the sutures from pulling through the graft, a problem that can occur with other types of polytetrafluoroethylene grafts. Two months after the patient was discharged, a bronchoscopy was carried out to evaluate the results of our repair, and no stenosis was observed.

To our knowledge, this is the first reported use of a ringed vascular graft in the repair of a tracheal rupture.
This technique appears to be appropriate for use in patients who have large tracheal ruptures.

\section{REFERENCES}

1. Leinung S, Möbius C, Hofmann HS, Ott R, Rüffert H, Schuster $\mathrm{E}$, et al. Iatrogenic tracheobronchial ruptures - treatment and outcomes. Interact Cardiovasc Thorac Surg 2006;5:303-6.

2. Liu H, Jahr JS, Sullivan E, Waters PF. Tracheobronchial rupture after double-lumen endotracheal intubation. J Cardiothorac Vasc Anesth 2004;18:228-33. CrossRef

3. Miñambres E, González-Castro A, Burón J, Suberviola B, Ballesteros MA, Ortiz-Melón F. Management of postintubation tracheobronchial rupture: our experience and a review of the literature. Eur J Emerg Med 2007;14:177-9. CrossRef

4. Massard G, Rougé C, Dabbagh A, Kessler R, Hentz JG, Roeslin N, et al. Tracheobronchial lacerations after intubation and tracheostomy. Ann Thorac Surg 1996;61:1483-7.

5. Borasio P, Ardissone F, Chiampo G. Post-intubation tracheal rupture. A report on ten cases. Eur J Cardiothorac Surg 1997;12:98-100. CrossRef

6. Hofmann HS, Rettig G, Radke J, Neef H, Silber RE. Iatrogenic ruptures of the tracheobronchial tree. Eur J Cardiothorac Surg 2002;21:649-52. CrossRef

7. Kaloud H, Smolle-Juettner FM, Prause G, List WF. Iatrogenic ruptures of the tracheobronchial tree. Chest 1997;112:774-8.

8. Hasse J. Patch-closure of tracheal defects with pericardium/ PTFE. A new technique in extended pneumonectomy with carinal resection. Eur J Cardiothorac Surg 1990;4:412-6.

9. Foroulis CN, Simeoforidou M, Michaloudis D, Hatzitheofilou K. Pericardial patch repair of an extensive longitudinal iatrogenic rupture of the intrathoracic membranous trachea. Interact Cardiovasc Thorac Surg 2003;2:595-7. CrossRef 